\title{
Higher-Order Utilitarian and Symbolic Antecedents of Brand Love and Consumers' Behavioral Consequences for Smartphones
}

\author{
Muhammad Asif Khan \\ (Corresponding Author) \\ Assistant Professor \\ Marketing Department, College of Business-Rabigh, \\ King Abdulaziz University, Jeddah, KSA \\ Email: khanasif79@gmail.com, mabkhan@kau.edu.sa
}

\section{Muhammad Zulqarnain}

Associate Professor

HR Department, King Abdulaziz University, Rabigh, KSA

hmzous@gmail.com

\section{Zeeshan Ahmed Bhatti}

Senior Lecturer

Department of Operations \& Systems Management

Portsmouth Faculty of Business \& Law

University of Portsmouth, UK PO1 3DE

zeeshan.bhatti@port.ac.uk

\section{Adnan Raza}

Scholar

Marketing Department, University of South Asia, Lahore, Pakistan

Joinadnan11@gmail.com 


\title{
Higher-Order Utilitarian and Symbolic Antecedents of Brand Love and Consumers' Behavioral Consequences for Smartphones
}

\begin{abstract}
Using categorization theory, this study explores the effects of higher order functional and symbolic benefits on brand love (BL). It further studies the relationships between BL and consumers' behavioral responses (positive word-of-mouth, willingness to pay price premium, resistance to negative information and brand loyalty). The data were collected from 321 smartphone users, applying cross-sectional design, and analyzed by PLS-Structural Equation Modeling. The results show that perceived functional and symbolic benefits significantly predict consumer's love for smartphone brands. Moreover, BL significantly mediates the relationships between higher order antecedents and behavioral outcomes. This study theoretically contributes to the BL literature by establishing the generalizability of BL measure and reassuring the universality of its consequences in Asian context for smartphone users.
\end{abstract}

Key Words: brand love, functional benefits, symbolic benefits, brand loyalty, premium prices, resistance 


\section{INTRODUCTION}

Consumers do not simply choose brands rather they choose ways of life (Bairrada et al., 2018). The brands, thus, not only aid consumers in their lives but also give meaning to their lives. On this notion, Ahuvia et al. (2009) propose that humans can develop love-based relationship with objects (including brands), as they do with other humans. Thus, marketing professionals and researchers focused their attention to investigate such consumer-brand attachment in the past (Hung and $\mathrm{Lu}$, 2018; Park et al., 2010). Homburg et al. (2009) suggest that in today's increasingly connected business environment, researchers should go beyond the constructs like customer satisfaction and focus more on the applications of consumer-brand relationships, for instance, BL, brand trust and brand commitment. They further emphasize that such consumer-brand linkages have significant results in terms of spreading positive word-of-mouth (WOM) and consumers' willingness to pay premium price (Batra et al., 2012; Malär et al., 2011).

Realizing the importance of consumer-brand emotional relationships, past researchers have proposed and empirically validated numerous BL antecedents such as brand satisfaction, brand credibility; perceive quality, brand intimacy, brand uniqueness and perceived value (Bagozzi et al., 2016; Bairrada et al., 2018; Carroll and Ahuvia, 2006; Roy et al., 2013). These individual attributes, varying on their level of abstraction, act as a specific cue in developing consumer-brand relationship. There may be a hierarchal order of abstraction among these attributes, such as perceived quality may lead to satisfaction. Similarly, brand awareness may lead to brand associations. Fewer researches have tried to study the hierarchical relationship or higher order pattern in terms of level of abstraction among these individual antecedents of BL (Bairrada et al., 2018). Past research show that higher the level of abstraction, higher will be the generalizability of the construct (Nunkoo, 2018). Individual attributes act as specific cue whereas a higher order construct are more abstract but provide simplified cues that help in decision-making and in developing emotional connection. The constructs with lower level abstraction develop love but with lesser intensity as compared to higher abstraction constructs that may develop love based relationship with higher intensity (Bairrada et al., 2018).

Drawing on categorization theory, this study divides previously explored antecedents of BL into two broad higher order categories such as perceived functional benefits (PFBs) and perceived symbolic benefits (PSBs). The purpose of this study is to explore a higher order pattern among 
these PFBs and PSBs constructs. Though Bairrada et al (2018) have made an effort to differentiate the constructs based on their level of abstraction and categorized the antecedents based on lower and higher level of abstraction. They further verified the inter relationships among those constructs, but did not explore the higher order pattern which is the main aim of our study. Hence, drawing on categorization theory complemented with Consumer-brand attachment theory, this paper contributes in the area of BL by establishing how higher order antecedents based on utilitarian and symbolic benefits to consumers contribute in developing consumers' love with smartphone brands and how that love in turn ends up in consumers' behavioral responses. We study the most popular correlates of BL based on their utilitarian and symbolic benefits for consumers to establish its nomological network and discriminant validity.

The extant research on BL is racked by different theoretical and conceptual frameworks of BL (Bairrada et al., 2018). This use of varied conceptualizations has rendered it difficult to compare directly the findings of the scarce studies conducted in the past to explore the antecedents of BL. There is, thus, a dire need to consolidate research around a single rigorous conceptualization of $\mathrm{BL}$ and a corresponding measure. One strength of this paper is that it is one of the first using the Bagozzi et al.’s (2016) BL scale that comes out of the Batra et al.’s (2012) work. Bagozzi et al.'s (2016) scale is much more empirically grounded than other conceptualizations of BL. It is based on an extensive qualitative study in Ahuvia (2005) and then a second, equally extensive qualitative study in Batra et al. (2012). Therefore, one contribution of this paper is helping tame the proliferation of BL definitions by building research momentum for the most well-grounded conception of BL and the most carefully validated BL scale, which also comes out of that conceptualization.

This paper first discusses the theoretical and conceptual framework that highlight the importance and scope of BL. Then it moves on to the higher order PFBs and PSBs as antecedents of BL, and subsequently it discusses the behavioral outcomes and hypotheses development. After methodology and analysis section, it discusses the key findings of this study. In the end, it explains the theoretical and practical implications of the findings, and limitations of the study along with potential research avenues. 


\section{THEORATICAL AND CONCEPTUAL FRAMWORK}

\section{Brand Love: The concept and its scope}

The notion of BL is, though no longer all that new, yet there has been an uptick in work on this construct in the past decade (Roy et al., 2013). The concept of BL evolved out of research on high involvement consumption led mostly by Bloch (1986). Shimp and Madden (1988) made the first conceptual link between this and theories of interpersonal love. From there, Ahuvia $(1992,1993)$ did the first extensive study specifically on love for products, brands, activities and possessions. This included BL but did not use that term since it also included other things people loved. Ahuvia (1993) thesis work eventually became Ahuvia (2005). During that period, Fournier (1998) published her seminal paper on consumer brand relationships, which included love as one of many possible relationships consumers can have with brands. The term 'BL' had been used very sporadically in the popular press, but became popularized by the Carroll and Ahuvia's (2006) primal paper on BL which also included the first BL scale.

The BL construct has been derived from the notion of interpersonal love in psychology (Carroll and Ahuvia, 2006; Shimp and Madden, 1988) and has been applied on consumer behavior. Albert et al. (2008), Lastovicka and Sirianni (2011) and Batra et al. (2012) explored BL through in-depth qualitative interviews about things that people love and compare this non-interpersonal love for brands with interpersonal love (Rauschnabel and Ahuvia, 2014). The difference in approach is that Carroll and Ahuvia (2006) and Shimp and Madden (1988) took psychological theories and directly transposed them to consumer behavior without doing any qualitative work to check for ways that might not be appropriate. Whereas Albert et al. (2008) and Batra et al. (2012) both started with the psychological literature on love but they carefully checked it against detailed qualitative work with consumers to develop their theories of BL.

In the past decade, several empirical studies have been conducted on BL (Albert et al., 2008; Bagozzi et al., 2016; Batra et al., 2012; Carroll and Ahuvia, 2006) with an evolution of measuring scales. Other constructs related to BL are also explored by the researchers e.g. BL has been explored in literature from one-dimensional (Carroll and Ahuvia, 2006) to eleven-dimensional construct (Albert et al., 2008) with differing conceptualizations. Carroll and Ahuvia (2006) propose that BL is a single and specific emotional reaction; whereas Batra et al. (2012) say that the word love has multiple meanings. One meaning does refer to an emotion that is also called 
affection or sometimes an emotion of passionate desire. The word love is also used to refer to a type of relationship, such as when people talk about loving products and brands, they are usually using the word love to refer to this type of relationship. It is due to the varied conceptualizations and definitions of BL that Batra et al. (2012) considered it as a complex and fuzzy construct. By using the prototype approach, they put forth a prototype model of BL by following the principle that complex and fuzzy constructs are best described by a prototype.

\section{Antecedents of Brand Love}

Our conceptual model is based on categorization theory (Rosch, 1978) which poses that individuals possess a structured view of the world and categorization serves as a simplification strategy to minimize environmental complexity. Alba and Hutchinson (1987) point out that differentiating objects to facilitate decision making is the key function of the categorization. Researchers have used categorization theory to explain consumer behavior in previous studies (Malär et al., 2012; Ülkümen et al., 2010). For instance, Malär et al. (2012) investigate how the intended brand personality is successfully developed through a number of features that facilitate brand categorization. Batra et al., (2012) and Fournier (1998) discussed that consumers may develop stronger love-based relationship with the brands superior on one or more attributes. Holbrook and Hirschman (1982) argue that experiential approach and information processing model are two complementary views of consumer behavior and can guide consumers to identify brand attributes having potential to develop stronger consumer-brand relationship.

Both the information processing and experiential models of categorization theory, thus reflect the view that brands can deliver both symbolic and functional benefits (Dhar and Wertenbroch, 2000). Previous studies have explored several product/brand attributes as antecedents of BL such as Batra et al. (2012) and Rauschnabel and Ahuvia (2014) explored brand/product quality as a key antecedent of BL. Brand anthropomorphism, which is a utilitarian attribute of a brand, is studied by Rauschnabel and Ahuvia (2014) and brand experience, self-congruity and brand personality, which are symbolic/experiential attributes explored by Biçakcıglu et al. (2016) and Rauschnabel et al. (2016). There is another stream of research that focuses on other conceptualizations of BL. These studies identify other variables as antecedents of BL including hedonic products and selfexpressive brands (Carroll and Ahuvia, 2006). While Albert et al. (2013) emphasize brand identification and brand trust as key antecedents, Vernuccio et al. (2015) propose social identity, 
and Roy et al. (2016) identify sincerity and excitement as key predictors of BL. In a theoretical paper, Roy et al. (2013) discuss a number of antecedents of BL; for instance, brand satisfaction, consumer delight, self-congruity, brand experience and romanticism. Recently, Bairrada, et al. (2018) also point out several utilitarian and symbolic traits of brands that may act as important antecedents of BL.

We, however, note that some antecedents of BL studied in the latter studies have conceptual overlap with some dimensions of the BL scale developed by Bagozzi et al. (2016). For example, Albert et al. (2013) note that brand commitment and WOM have overlapping with brand passion. It cautions us that selecting some antecedents of BL may have important pay-offs (Bairrada et al., 2018). Our conceptual framework is not only based on key antecedents of BL but also further categorize them into higher order PFBs and PSBs of brands contributing in development of BL.

So, in this study, rather than modeling individual utilitarian/functional and symbolic benefits as antecedents of BL, we propose higher-order constructs named as PFBs and PSBs based on the predominantly tangible and intangible nature of the attributes as antecedent of BL. The PFBs are usually associated with objective features that address the consumption needs that are externally determined (Park et al., 1986) whereas aesthetic and hedonic features that encompass the needs which are internally determined are associated with PSBs. Bairrada et al. (2018) argue that PFBs and PSBs may contribute to the development of BL.

\section{Perceived Functional Benefits}

This study include product quality and brand satisfaction as functional antecedents of BL considering their predominantly utilitarian nature driving customer utility perceptions. The rationale for this proposition is discussed in the following section.

Perceived Quality. Literature says it is “customer's perception of overall quality or superiority of a product or service relative to alternatives" (Tuominen, 1999: 83). Consumer behavior research has established the importance of perceived quality by positioning it as a key variable for brand equity (Aaker, 1991; Netemeyer et al., 2004). Quality is the pivotal reason to buy associated with performance of the product in meeting customer needs. It provides the basis for consumers to love brands. It influences consumer decision-making regarding 'which brand to include or exclude from their consideration set and which brand is to be selected?' It also helps in product positioning and a higher perceived quality product may have the advantage of charging a premium price. In BL 
literature, perceived quality having utilitarian benefits has established its important contributions (Bagozzi et al., 2016; Batra et al., 2012; Rauschnabel and Ahuvia, 2014).

Brand Satisfaction. According to Fournier and Mick (1999), satisfaction is a post purchase attitude like judgment based on a series of consumer-product interactions. The cumulative satisfaction over a period leads to an emotional bonding between consumer and brand. This study uses brand satisfaction as a proxy variable by measuring consumers' level of satisfaction with most relevant brand attributes. This practice of using satisfaction as a proxy variable is in line with the past research (Chadee and Mattsson, 1996; Vemuri and Costanza, 2006; Yoo and Donthu, 2001). We operationalize brand satisfaction as a construct comprising consumers' post-consumption evaluative judgment including cognitive and affective (Roy et al., 2013) components. Brand satisfaction, thus, approximates the utilitarian attributes of the smartphone brands and acts as a summary construct. Bairrada et al. (2018) also use this approach for operationalizing 'brand prestige' as a summary construct for the brand attributes of quality, globalness and scarcity. Thus, we propose that:

$H_{1}$ : Perceived functional benefits positively influence consumer's love for smartphone brands. **** Insert Figure 1 about Here ****

\section{Perceived Symbolic Benefits}

A brand is composed of tangible and intangible elements. Generally, a strong brand is developed on intangible attributes. These attributes take a place in consumer's mind and cannot be copied easily or transferred (Keller, 2003). This study considers brand awareness, brand associations and perceived symbolic differentiation (PSD) as key components of PSB of brands due to their predominantly intangible nature that drives customers' perceptions regarding symbolic benefits of brads.

Brand Awareness. The concepts of brand awareness and brand association are derived from the Aaker (1991) model of brand equity theory. Brand awareness is the strength of the brand that reflects in terms of consumer's ability to identify under different conditions. It is defined in terms of consumer's knowledge or familiarity about the features, liking of image and status of the brand. Brand awareness comprises of recognition and recall. Recognition is consumer's ability to identify the brand on the basis of previous exposure. This exposure can be in terms of utility or a symbolic cue of brand encounter. In this study, we consider brand recognition based on symbolic cues. Brand 
recall is consumer's ability to retrieve the brand from his memory in a given product category at the time of inquiry or purchase. Keller (1993) says that brand recognition plays important role in product purchase decision in the store. It also influences the formation and strength of brand associations with reference to brand image.

Brand Associations. Brand associations may develop on different product related or non-product related associations that include functional or symbolic benefits, product classes, competitors and country of origins. Broadly, brand associations can be classified into three types such as attributes, benefits and attitudes (Tuominen, 1999). This study, particularly focus on the associations linked to symbolic brand benefits. Such benefits are related to the subjective value and meaning that consumers give to the product or service. The underlying motivation for these benefits associations may be of functional, experiential or symbolic. Functional benefits are more intrinsic whereas symbolic benefits are more extrinsic advantages of product or service. Symbolic benefits are usually correspond to non-product related attributes with underlying needs for personal expression and social approval (Tuominen, 1999). Symbolic benefits are sought especially for socially visible products. This study, however, operationalizes brand associations only in symbolic terms excluding other realms.

Perceived Symbolic Differentiation. Netemeyer et al. (2004) defined brand differentiation/ uniqueness as the degree to which consumers perceive or feel the brand is different from other competing brands. It is human need to feel differentiated from others, which they achieve through product consumption that enhance their self-concept. Social identity theory suggests that individuals put efforts to be similar to their in-group and at the same time need to be different from the out-group. A symbolically differentiated brand contributes to the need of being differentiated from others. It helps the individual in satisfying his/her ego-identification needs. Albert et al. (2008) found in qualitative study that consumers referred their favorite brand as unique and different. Customers may pay higher premium if they perceive symbolic differential between their loved brand and other brands. Hence, based on above arguments, we propose that:

$H_{2}$ : Perceived symbolic benefits positively influence consumer's love for smartphone brands. 


\section{Behavioral Outcomes of Brand Love}

Although it is not the main objective of this study to establish the relationship between BL and its outcomes, but to proposed and establish the mediating role of BL between PFBs and PSBs and behavioral outcomes, we took previously established outcomes of the BL such as positive WOM (Batra et al., 2012; Carroll and Ahuvia, 2006), willingness to pay price premium (Garg et al., 2016; Liu et al., 2018), resistance to negative information (Bagozzi et al., 2016; Turgut and Gultekin, 2015) and brand loyalty (Carroll and Ahuvia, 2006; Khamitov et al., 2019).

\section{Positive Word-of-Mouth}

Consumer-brand relationship based on emotional and passionate attachment may lead a consumer to say positive things about the brand in their social networks. Positive WOM is the degree to which the consumer says positive things about a brand to others (Westbrook, 1987). Bergkvist and Bech-Larsen (2010) included positive WOM in their study as a component of active engagement. They conclude that consumers' love based relationship with the brands actively engages them to visit brands' websites and share their opinions about brands in their social networks online or offline. Consumers are willing to invest their time and energy in spreading positive things about their loved brands. Sheth (1971) and Day (1971) confirm that WOM is more important and nine times as effective as advertising in securing a positive attitude to try a product. Several studies show a positive relationship between BL and positive WOM for brands (Carroll and Ahuvia, 2006; Roy et al., 2013). Thus, we hypothesize that high consumer's love towards brand leads to more positive WOM.

$H_{3}$ : Consumer's love for smartphone brands positively influences positive WOM.

\section{Willingness to Pay Price Premium}

Price premium is the amount that customer is willing to pay higher for a brand as compared to competing brands in the same category (Aaker, 1996). Price premium is considered as the most useful indicator of strong brand equity (Aaker, 1996; Sethuraman, 2001) and a relevant outcome of BL (Batra et al., 2012; Garg et al., 2015; Liu et al., 2018; Rodrigues et al., 2015). Doyle (2001) argue that price premium helps in enhancing shareholder value because it does not need any direct investment to charge high price. Although price premium has an important place in branding theory, yet it requires further empirical support about which specific type of brand attachment it 
should be built upon (Anselmsson et al., 2014; Hung and Lu, 2018). Customers pay higher premium if they perceive quality differential between their loved brand and other brands. Previous researchers, for instance, Thomson et al. (2005), Batra et al. (2012, p.12); and Liu et al. (2018), demonstrate support for the relationship between BL and willingness to pay price premium. Hence, we predict as follows:

$H_{4}$ : Consumer's love for smartphone brands positively influences willingness to pay price premium.

\section{Resistance to Negative Information}

Consumer's resistance to negative information about the brand/firm has been explored in consumer behavior literature (Batra et al., 2012; Marin et al., 2009; Turgut and Gultekin, 2015). Previous studies conclude that consumers build stronger relationship with those firms that care their best interests through brand attributes (Batra et al., 2012). Eventually, consumers care about how they are treated and what they get in terms of products/brands. Not surprisingly, Bhattacharya and Sen (2003) conclude that consumers are more likely to forgive a company's mistakes if they feel connected with it. It is a relationship based on the norm of reciprocity, i.e. the more a company cares about its consumers, the more they will be inclined to resist against negative information about that brand. Ahearne et al. (2005) and Ahuvia et al. (2009) find that loved brands become part of consumers' identity and in that sense they tend to resist negative information about themselves. Thus, we propose as following:

$H_{5}$ : Consumer's love for smartphone brands positively influences consumer's resistance to negative information about the brand.

\section{Brand Loyalty}

Brand loyalty is the consistent purchase of a brand over time because of positive and favorable attitude towards that brand. Marketing literature describe two approaches in defining brand loyalty, namely behavioral and cognitive. Behavioral approach view consistent buying of a brand over time whereas, cognitive approach implies a commitment to a brand that may not be reflected by measuring consumer repeated behavior (Tuominen, 1999). For instance, a low cost brand may be purchased because of its lowest price on the market. A slight increase in price may induce the consumer to shift to another low cost brand. In this case, repeat purchase is not the true 
representation of brand loyalty. Brand loyalty is a complex construct reflecting from the habitual buyer to the satisfied buyer who like the brand with true commitment and feel pride in being the user of that brand. Carrol and Ahuvia (2006) empirically established that satisfied consumers are emotionally committed with the brand that leads to repurchase of that brand. In a similar vein, we predict as follows:

H6: Consumer's love for smartphone brands positively influences brand loyalty.

\section{Brand Love as a Mediator}

According to Hayes (2013), one can establish the causal relationship between $\mathrm{X}$ and $\mathrm{Y}$ but it is always more interesting to know the underlying mechanism through which the causal effect operates. The mechanism is studied under mediation analysis (Baron and Kenny, 1986; Hayes, 2013; Zhao et al., 2010) with the existence of an indirect effect of X (independent variable) on Y (dependent variable) through mediator(s) (M) variable(s).

Bagozzi (1992) proposes the principle that appraisal leads to emotional responses. Each brand quality/attribute (PFB and PSB) included in our model involves an appraisal. Thus, the brand attributes measured through functional and symbolic attributes are proposed to directly affect BL as well as the outcome variables. It implies that BL mediates the relationships between functional benefits and symbolic benefits and outcome variables. Though, past research signals a partial mediation role for BL (Bairrada et al., 2018), it does not offer definite answers in this regard (Bagozzi et al., 2016) and warrants further research. Hence, we propose as follows:

H7: Consumer's love for smartphone brands mediates the relationship between PFBs and (a) positive WOM, (b) willingness to pay price premium, (c) resistance to negative information, and (d) brand loyalty.

H8: Consumer's love for smartphone brands mediates the relationship between PSBs and (a) positive WOM, (b) willingness to pay price premium, (c) resistance to negative information, and (d) brand loyalty.

\section{METHODOLOGY}

Data were collected from general consumers of smartphone brands through self-administrated questionnaires. We choose consumers' love for smartphones brands because smartphones are 
among the most frequently and passionately used products by the consumers due to various lively “anthropomorphism” features and attractions for users (Rauschnabel \& Ahuvia, 2014). The other reason that the smartphone industry is one of the biggest industries in Pakistan. According to PTA (Pakistan Telecommunication Authority), more than 150 million people are using mobiles of different companies in Pakistan including almost all major brands of the world (PTA, 2018).

Measures. We adapted the items from scales that have already been used in many past studies. $B L$ was measured with 6 dimensions ${ }^{1}$ i.e. (1) Self-Brand Integration (SBI), (2) Passion-Driven Behaviors (PDB), (3) Positive Emotional Connections (PEC), (4) Long-Term Relationship (LTR), (5) Anticipated Separation Distress (ASD), and (6) Attitude Valence (AV) based on Batra et al. $(2012)^{2}$. The questions were rephrased so that respondents could focus on their favorite smartphone brands. For instance, 'concerning your favorite smartphone brand, to which extent do you agree with the following statements'? Respondents rated all items measuring BL on a 7-point likert scale ranging from 1 (Not at all) to 7 (Very much) as per the recommendations of Batra $e t$ al. (2012) and Bagozzi et al. (2016).

The higher order PFB construct consists of perceived quality and brand satisfaction where, 'perceived quality' was measured with three items adapted from Washburn and Plank (2002). Brand satisfaction was measured with eight items based on the measures of Oliver (1980), Churchill and Surprenant (1982) and Brakus et al. (2009). The higher order PSB construct consists of three constructs adapted from Washburn and Plank (2002) and Loureiro and Kaufmann (2012) articulated as brand awareness measured with three items, brand associations to symbolic benefits measured with four items and PSD measured with three items as consumers perceived differences when the brands have similar features.

Positive WOM was assessed with three items adapted from Zeithaml et al. (1996) and Batra et al. (2012). Willingness to pay price premium was measured with three items adapted from Anselmsson et al. (2014) and Batra et al. (2012). Resistance to negative information about their favorite brand was measured with four items adapted from Eisingerich et al. (2011) and Brand loyalty was measured with 6 items adapted from Chaudhuri and Holbrook (2001) and Carroll and

\footnotetext{
${ }^{1}$ Rauschnabel and Ahuvia (2014) and Bagozzi et al. (2016) found that seventh dimension "Attitude Strength 2" was not significant with remaining constructs of BL. Since the respondents did not consider it a part of BL construct in their study so, we did not include it in our study.

${ }^{2}$ Bagozzi et al. (2016) used BL as a single factor in their study by computing the averages of items. Alternatively, we used factor scores of first and second order constructs to ensure more representation of variance measured in the BL construct (Hair et al., 2009; Tabachnick and Fidell, 2013).
} 
Ahuvia (2006). (See Appendix I). All items were measured on 7-points Likert scale from (1) strongly disagree to (7) strongly agree. Finally, consumers' gender, age, income, and qualification were included as control variables.

Descriptive statistics. Descriptive statistics (mean, standard deviations and correlations) of the main variables were provided in Table 1.

$* * * *$ Insert Table 1 about here $* * * *$

Sample statistics. A sample of 321 valid respondents was collected to analyze the data. Males were $224(69.8 \%)$ and females were 97 (30.2\%). In qualification, 301 (93.8\%) had graduate level education or more. Whereas, $258(80.4 \%)$ respondents were from "less than or equal to 30 years" that represented youth of the population and made it more representative sample of smartphone users with average income of \$204. Moreover, 224 (69.8\%) respondents came from student's category that made it a good mixture of students and professionals.

Measurement validation. The measurement model was validated, using PLS-SEM employing WarpPLS statistical software version 6.0, with average path coefficient, average variance inflation factor, and average full collinearity (Kock, 2015). PLS-SEM has a vast potential for SEM researchers especially in the marketing discipline (Hair et al., 2011). It is a partial least squares regression based approach that minimize the residual variances of the endogenous constructs. It has less identification issues, equally works well for small and large samples and can be used for both formative and reflective constructs. Model's explanatory power is measured with Tenenhaus's goodness of fit (GoF). Wetzels et al. (2009) proposed the criteria that explanatory power is small if $\mathrm{GoF} \geq .10$, medium if $\mathrm{GoF} \geq .25$, and large if $\mathrm{GoF} \geq .36$. In our model $\mathrm{GoF}=.285$ which shows medium explanatory power of the model. All the quality indices met recommended criteria, suggesting that our model has a good fit (Table 2).

**** Insert Table 2 about here ****

Exploratory factor analysis (EFA) suggested two factors of brand satisfaction, namely, cognitive and affective. The analysis used factor scores of the two dimensions to measure the higher order PFB construct. Overall, the factor structure worked out satisfactorily (Table 1). Composite reliabilities and Cronbach's alpha coefficients are all higher than .70 (Appendix I); average 
variances extracted for all constructs are higher than the minimal cut-off of .50 (Hair et al., 2009). Factor loadings are good, higher than the commonly used cut-off of .70. Thus, our measures demonstrated adequate convergent validity and reliability

We also assessed discriminant validity using Fornell and Larcker's (1981) procedure. Average variance extracted for each construct was much higher than all the squared correlation coefficients between the pairs of latent variables. Hence, discriminant validity was established (Table 1).

Common Method Variance Assessment. Cross-sectional research design and self-reported data collection technique prone to common method variance (CMV). To address CMV, this study took procedural and statistical remedies. Procedural remedies include different response formats and a counterbalancing question order (Podsakoff et al., 2003). For instance, we asked respondents about antecedents before asking for outcomes to avoid priming effects. Whereas statistical remedy for CMV is the most commonly used Harman's single factor test based on percentage of total variance extraction (Podsakoff et al., 2003). We performed EFA with all the items in the study and found that no single factor accounted for more than $50 \%$ of variance. All the factors account for $72.77 \%$ of total variance with first factor accounted for only $26.30 \%$. This implies that CMV is not a serious threat in our study.

\section{ANALYSIS AND RESULTS}

Results of PLS based structural equation modeling are reported in this section (see Table 3). The result about hypothesis $\mathrm{H}_{1}$ showed that as expected, higher order construct $\operatorname{PFB}(\beta=.482, p<.001)$ has positive significant effect on BL. Similarly, H2, the higher order construct PSB $(\beta=.145$, $p<.01)$ has positive significant effect on BL. Moreover, all the lower order constructs significantly constitute higher order constructs. Our hypotheses $\left(\mathrm{H}_{3}-\mathrm{H}_{6}\right)$ related to $\mathrm{BL}$ and its outcomes, i.e. positive $\operatorname{WOM}(\beta=.247, p<.001)$, willingness to pay price premium $(\beta=.245, p<.001)$, resistance to negative information $(\beta=.195, p<.001)$, and brand loyalty $(\beta=.211, p<.001)$ were all supported.

**** Insert Table 3 about here ****

\section{Mediation Results}

We calculated the indirect/mediating effects of the IVs on DVs through BL applying the Aroian version of the Sobel test suggested in Baron and Kenny (1986) and recommended by Preacher and 
Hayes (2004) because it is less fallible to Type I error especially in case of large samples. As suggested by Preacher and Hayes (2008), we further calculated the bootstrapped confidence intervals of the indirect effects by using a more sophisticated and rigorous procedure based on normal approximation (Monte Carlo) method proposed by Falk and Biesanz (2016). The results of indirect effects of PFBs and PSBs on outcome variables (PWOM, premium price, RTNI and band loyalty) through BL are reported in Table 4. The results of Aroian test and Monte Carlo normal approximation methods converge in our case and support the mediation hypotheses proposed in this study.

**** Insert Table 4 about here $* * * *$

\section{GENERAL DISCUSSION}

This study is conducted realizing the importance and popularity of BL among marketing practitioners and academics. Our findings provide some theoretical and managerial implications in this regard. Building an emotional connection with higher-order constructs, marketing managers can devise strategies to create love in consumers for building long-term relationship and capitalizing on it.

Our results support the notion that consumers' perceived functional and symbolic benefits are strong predictors of BL consistent with the previous findings (Carroll and Ahuvia, 2006; Loureiro and Kaufmann, 2012; Roy et al., 2013). PFBs associated with perceived quality and customer satisfaction related to functional attributes are more likely to develop strong feelings of love towards their smartphone brands as compared to the PSBs in brands. This is evident by a higher beta value $(\beta=.482, p<.001)$ for PFB as compared to the PSB $(\beta=.145, p<.01)$. This is an important finding that PFBs contribute more towards love as compared to PSBs. Contrary to previous work that studied the effects of certain functional and symbolic attributes of brands separately (Bairrada et al., 2018), this study not only provides evidence regarding the contributions of higher-order functional and symbolic benefits of brands in developing BL but also provides an evidence regarding their respective (comparative) strengths of relationships with BL, which is an important contribution towards BL literature.

The consequences of BL are also important for the marketers. Our study empirically proves that positive WOM, willingness to pay price premium, resistance to negative information and brand loyalty are the significant outcomes of BL. Consistent with previous research (Bairrada et al., 
2018; Carroll and Ahuvia, 2006; Roy et al., 2013). Our findings, thus, reassure the universality of BL outcomes. When the brand occupies a special place in consumer's mind and life, then $\mathrm{s} / \mathrm{he}$ develops a long term relationship with the brand (Ahuvia et al., 2009). This valuable and unique relationship with the brand leads customers to preserve it for longer time, even under the circumstances wherein s/he has to pay a higher price for that brand. This relationship also fosters willingness to spread positive WOM and resist the negative information about that brand. Regarding the indirect effects of BL on outcomes, our results are consistent with Roy et al. (2013) that customers with perceived benefits (functional and symbolic) having strong BL show more positive WOM as compared to those without love bonding. Our findings also suggest that the relationship between consumers perceived benefits (functional and symbolic) and consumer response in terms of loyalty is not straightforward; rather it may need a mediating mechanism to perform in positive way. Literature has mix findings such as loyal customers are satisfied but not all satisfied customers are loyal (Oliver, 1999) or are ready to share positive WOM, but not ready to pay price premium. Oliver (1999) worked on six possible relations of satisfaction with outcomes and conclude that consumer satisfaction is a transitioning stage in consumer behavior. Our findings support this view as we can see BL mediates the relationship between higher order construct of perceived quality and brand satisfaction and the outcomes.

Further, Our results support Bhattacharya and Sen's (2003) argument that consumers with love bonding are more likely to stand with company at their difficult times. The mediating effect of BL between perceived benefits (functional and symbolic) and resistance to negative information explains that customers with emotional bonding with company/brand are more likely to resist against negative information and also willing to pay high price for their loved brand.

\section{Theoretical Contributions}

Our work employed BL measurement scale developed by Batra et al. (2012) and Bagozzi et al. (2016) that has not been widely applied and requires validation across the world. This study contributes to BL literature by providing evidence of its validation and justification that this scale can be used to measure BL in South Asian context.

This study further contributes in establishing the nomological validity of BL by demonstrating the statistical evidence of significance of its relationships with its higher order antecedents and behavioral consequences. There have been very few studies explaining the underlying mechanism 
of relationships among BL correlates and even their findings are inconclusive about the mediating role of BL. This study thus contributes BL literature by providing the evidence in favor of its mediating role between the proposed higher-order antecedents and consequences.

\section{Practical Implications}

This study proposes some insights to the managers about how to spur BL and capitalize on it by carefully utilizing its higher-order antecedents. Consumers make decision about products/brands by taking into account attributes or benefits at both higher level of abstraction (higher-level construal) and lower level of abstraction (directly observed). When the attributes of the product/brands are not very much distinctive than competitors (e.g., in the case of smartphones) then, instead of directly observed attributes (lower-level abstraction), consumer make decision on a higher level of abstraction (e.g., brand/company reputation or performance in general) (GinkelBieshaar, 2012). Thus, it is important for marketing managers to facilitate consumer decisionmaking position their products/brands at a higher level of abstraction.

The outcomes of BL are also very important for marketing managers. As demonstrated from our results, in line with previous findings (Batra et al., 2012; Carroll and Ahuvia, 2006; Roy et al., 2013), customers are more willing to spread positive WOM as a result of love based connection with the brands. Similarly, consumers are ready to pay even higher premium for their loved brands. In addition, consumers have a strong emotion to defend brand's position in the market and resist against any negative information about their loved brands. Hence, managers should strive for development of such unique love based relationship with their consumers.

Positive emotional connection and positive feelings are two different concepts. Positive feelings may exist for a short and specific time but positive emotional connection shows a strong bond and long-term relationship between consumer and brand like an old school friend. Managers should strive for consumer brand emotional connection by developing brands with real spirit of functional and symbolic attributes. Marketing managers create brands with utmost efforts to capture a unique place in the minds and hearts of consumers based on their utilitarian/functional and symbolic benefits to consumers. In our study, most of the respondents mentioned iPhone as their loved brand and demonstrated the reason was higher levels of PFBs. This implies that satisfaction with functional attributes leads to strong bonding between customers and brands. Hence, brand 
managers should try to communicate brand signals fostering consumer utilitarian perceptions to harvest the benefits of BL.

Moreover, firms have increasing focus on marketing return on investment; one way for marketing managers is to develop their brand in a way that it becomes consumers' desired identity that expresses important values that consumer can relate with him/herself and feel an emotional deeper connection with brand.

\section{Limitations and Future Directions}

No research is without limitations; our research also has some limitations that may provide opportunities for future research. First, we applied a cross-sectional survey design to conduct the study in line with the previous studies (e.g., Batra et al., 2012; Bagozzi et al., 2016; Bairrada et al., 2018) in this field. This design has its limitations along with several advantages related to exploring the perceptions based constructs and their extended nomological networks, otherwise difficult to study. Cross-sectional surveys, however, are unable to address the changes in brand associations and consumers' perceptions over time (Warren et al., 2019). We, therefore, recommend that future studies may explore the antecedents and consequences of BL construct using a longitudinal design. Second, in our study BL was explored for smartphones in an eastern culture, future studies may explore other sectors of economic consumption such as cars, perfumes, and electronics brands. Third, this study treats BL as a composite measure (based on factor scores of each dimension of BL enabling it to capture more variance of its indicators) future studies may explore the relationship of BL in all possible sub-constructs instead of an overall construct. In addition, comparative findings based on cross-cultural research would be interesting to explore cultural effects on BL dimensions. Fourth, We followed the approach used by Batra et al. (2012) in measuring BL construct based on 56 items. Although, the measurement was satisfactory and validated but it's a complex method to measure BL. Future studies may use BL scale based on 6-, 13- and 26-items proposed by Bagozzi et al. (2016).

\section{Declaration of Conflicting Interests}

The author(s) declared no potential conflicts of interest with respect to the research, authorship, and/or publication of this article.

\section{Funding}


The author(s) received no financial support for the research, authorship, and/or publication of this article.
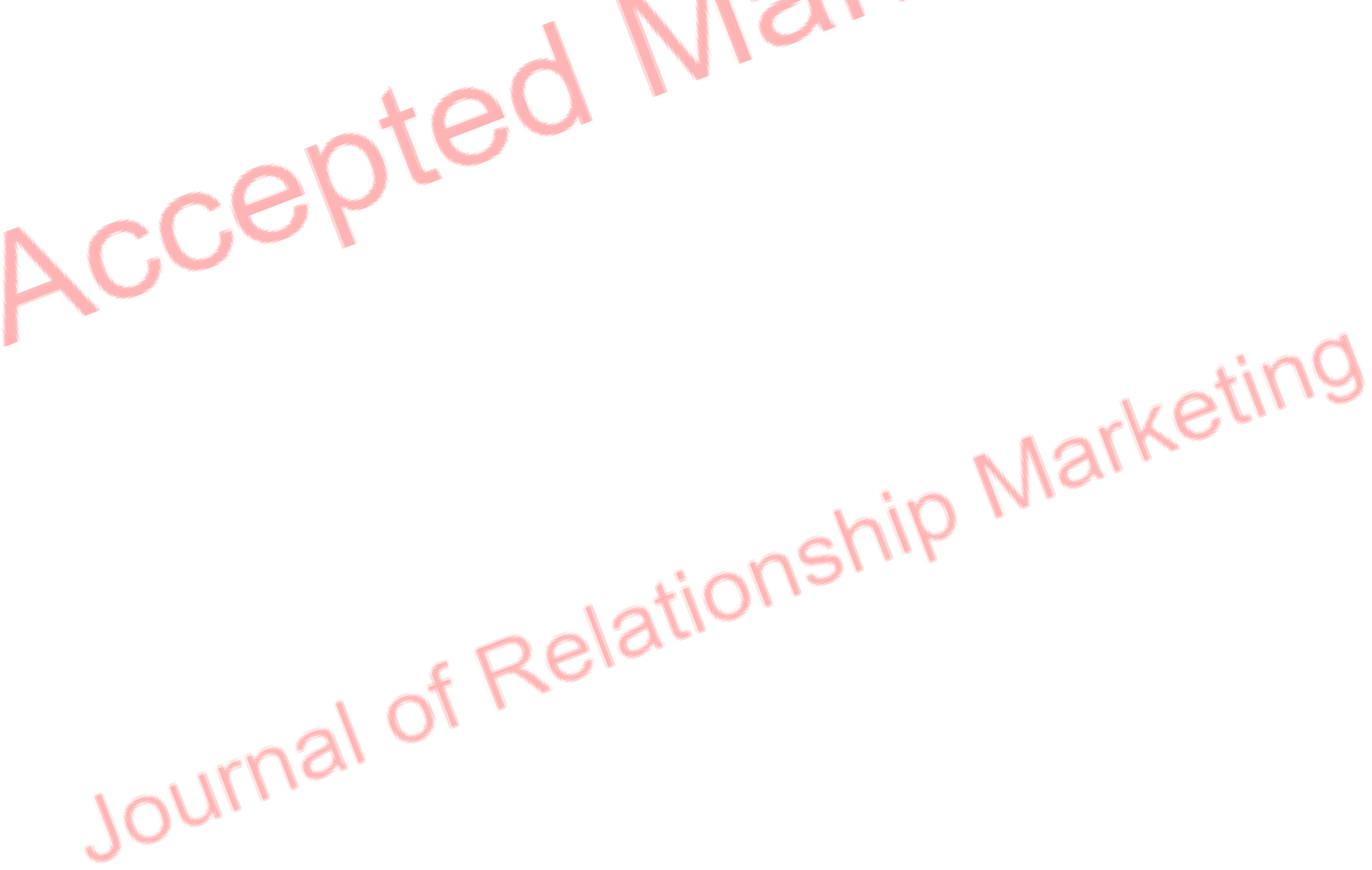


\section{REFERENCES:}

Aaker DA (1991) Managing Brand Equity: Capitalizing on the Value of a Brand Name. NY: Free Press.

Aaker DA (1996) Building Strong Brands. New York, Free Press.

Ahearne M, Bhattacharya CB and Gruen T (2005) Antecedents and consequences of customer-company identification: expanding the role of relationship marketing. The Journal of Applied Psychology 90(3): 574-585. DOI: 10.1037/0021-9010.90.3.574.

Ahuvia A (1992) For the Love of Money: Materialism and Product Love. In: Meaning, Measure, and Morality of Materialism. Provo, UT: Association for Consumer Research, pp. 188-198.

Ahuvia A (1993) I love it! : towards a unifying theory of love across diverse love objects. PhD Dissertation. Northwestern University, UMI Dissertation Services, Ann Arbor, MI. Available at: https://deepblue.lib.umich.edu/handle/2027.42/35351 (accessed 6 September 2019).

Ahuvia A (2005) Beyond the extended self: Loved objects and consumers' identity narratives. Journal of Consumer Research 32(1): 171-184. DOI: 10.1086/429607.

Ahuvia A, Batra R and Bagozzi RP (2009) Love, desire and identity: a conditional integration theory of the love of things. In: The Handbook of Brand Relationships, . New York: ME Sharpe, pp. 342357.

Alba JW and Hutchinson JW (1987) Dimensions of Consumer Expertise. The Journal of Consumer Research 13(4): 411-454.

Albert N, Merunka D and Valette-Florence P (2008) When consumers love their brands: Exploring the concept and its dimensions. Journal of Business Research 61(10): 1062-1075.

Anselmsson J, Bondesson NV and Johansson U (2014) Brand image and customers' willingness to pay a price premium for food brands. Journal of Product \& Brand Management 23(2): 90-102. DOI: 10.1108/JPBM-10-2013-0414.

Bagozzi RP (1992) The Self-Regulation of Attitudes, Intentions, and Behavior. Social Psychology Quarterly 55(2): 178-204.

Bagozzi RP, Batra R and Ahuvia A (2016) Brand love: development and validation of a practical scale. Marketing Letters: 1-14. DOI: 10.1007/s11002-016-9406-1.

Bairrada CM, Coelho F and Coelho A (2018) Antecedents and outcomes of brand love: utilitarian and symbolic brand qualities. European Journal of Marketing 52(3/4): 656-682. DOI: 10.1108/EJM02-2016-0081.

Baron RM and Kenny DA (1986) The moderator-mediator variable distinction in social psychological research: conceptual, strategic, and statistical considerations. Journal of Personality and Social Psychology 51(6): 1173-1182.

Batra R, Ahuvia A and Bagozzi RP (2012) Brand love. Journal of Marketing 76(2): 1-16. DOI: 10.1509/jm.09.0339. 
Bergkvist L and Bech-Larsen T (2010) Two studies of consequences and actionable antecedents of brand love. Journal of Brand Management 17(7): 504-518. DOI: 10.1057/bm.2010.6.

Bhattacharya CB and Sen S (2003) Consumer-Company Identification: A Framework for Understanding Consumers' Relationships with Companies. Journal of Marketing 67(2): 76-88. DOI: $10.2307 / 30040524$.

Bıçakcıoğlu N, İpek İ and Bayraktaroğlu G (2016) Antecedents and outcomes of brand love: the mediating role of brand loyalty. Journal of Marketing Communications 24(8): 863-877. DOI: 10.1080/13527266.2016.1244108.

Bloch PH (1986) 'Product Enthusiasm: Many Questions, a Few Answers' in NA-Advances in Consumer Research Volume 13, eds. Richard J. Lutz, Provo. UT: Association for Consumer Research: 539543.

Brakus JJ, Schmitt BH and Zarantonello L (2009) Brand Experience: What Is It? How Is It Measured? Does It Affect Loyalty? Journal of Marketing 73(3): 52-68.

Carroll BA and Ahuvia A (2006) Some antecedents and outcomes of brand love. Marketing Letters 17(2): 79-89. DOI: 10.1007/s11002-006-4219-2.

Chadee DD and Mattsson J (1996) An Empirical Assessment of Customer Satisfaction in Tourism. The Service Industries Journal 16(3): 305-320. DOI: 10.1080/02642069600000030.

Chaudhuri A and Holbrook MB (2001) The Chain of Effects from Brand Trust and Brand Affect to Brand Performance: The Role of Brand Loyalty. Journal of Marketing 65(2): 81-93. DOI: 10.1509/jmkg.65.2.81.18255.

Churchill GA and Surprenant C (1982) An Investigation into the Determinants of Customer Satisfaction. Journal of Marketing Research 19(4): 491-504. DOI: 10.2307/3151722.

Day GS (1971) Attitude change, media and word of mouth. Journal of Advertising Research 11(6): 3140.

Dhar R and Wertenbroch K (2000) Consumer Choice Between Hedonic and Utilitarian Goods. Journal of Marketing Research 37(1): 60-71. DOI: 10.1509/jmkr.37.1.60.18718.

Doyle P (2001) Shareholder-value-based brand strategies. Journal of Brand Management 9(1): 20-30. DOI: $10.1057 /$ palgrave.bm.2540049.

Eisingerich AB, Rubera G, Seifert M, et al. (2011) Doing Good and Doing Better despite Negative Information?: The Role of Corporate Social Responsibility in Consumer Resistance to Negative Information. Journal of Service Research 14(1): 60-75. DOI: 10.1177/1094670510389164.

Falk CF and Biesanz JC (2016) Two Cross-Platform Programs for Inferences and Interval Estimation About Indirect Effects in Mediational Models Two Cross-Platform Programs for Inferences and Interval Estimation About Indirect Effects in Mediational Models. SAGE Open 6(1): 2158244015625445. DOI: 10.1177/2158244015625445.

Fornell C and Larcker DF (1981) Evaluating Structural Equation Models with Unobservable Variables and Measurement Error. Journal of Marketing Research 18(1): 39-50. DOI: 10.2307/3151312. 
Fournier S (1998) Consumers and Their Brands: Developing Relationship Theory in Consumer Research. Journal of Consumer Research 24(4): 343-353. DOI: 10.1086/209515.

Fournier S and Mick DG (1999) Rediscovering Satisfaction. The Journal of Marketing 63(4): 5-23. DOI: $10.2307 / 1251971$.

Garg R, Mukherjee J, Biswas S, et al. (2015) An investigation of antecedents and consequences of brand love in India. Asia-Pacific Journal of Business Administration 7(3): 174-196. DOI: 10.1108/APJBA-09-2014-0112.

Garg R, Mukherjee J, Biswas S, et al. (2016) An Investigation Into the Concept of Brand Love and Its Proximal and Distal Covariates. Journal of Relationship Marketing 15(3): 135-153. DOI: 10.1080/15332667.2016.1209047.

Ginkel-Bieshaar V (2012) The Impact of Abstract versus Concrete Product Communications on Consumer Decision-making Processes. ERIM PhD Series Research in Management, Erasmus Research Institute of Management. Available at: https://www.erim.eur.nl/doctoralprogramme/phd-in-management/phd-tracks/detail/899-the-impact-of-abstract-versus-concreteproduct-communications-on-consumer-decision-making-processes/ (accessed 25 November 2019).

Hair JF, Ringle CM and Sarstedt M (2011) PLS-SEM: Indeed a Silver Bullet. Journal of Marketing Theory and Practice 19(2): 139-152. DOI: 10.2753/MTP1069-6679190202.

Hair JFJr, Anderson RE, Tatham RL, et al. (2009) Multivariate Data Analysis. 7th Ed. New Jersey: Prentice-Hall.

Hayes AF (2013) Introduction to Mediation, Moderation, and Conditional Process Analysis: A Regression-Based Approach. New York: Guilford Press. Available at: https://www.guilford.com/books/Introduction-to-Mediation-Moderation-and-ConditionalProcess-Analysis/Andrew-Hayes/9781609182304 (accessed 31 May 2017).

Holbrook MB and Hirschman EC (1982) The Experiential Aspects of Consumption: Consumer Fantasies, Feelings, and Fun. The Journal of Consumer Research 9(2): 132-140.

Homburg C, Wieseke J and Hoyer WD (2009) Social Identity and the Service-Profit Chain. Journal of Marketing 73(2): 38-54. DOI: 10.1509/jmkg.73.2.38.

Hung H-Y and Lu H-T (2018) The rosy side and the blue side of emotional brand attachment. Journal of Consumer Behaviour 0(0). DOI: 10.1002/cb.1712.

Keller KL (2003) Brand Synthesis: The Multidimensionality of Brand Knowledge. Journal of Consumer Research: An Interdisciplinary Quarterly 29(4). Journal of Consumer Research: An Interdisciplinary Quarterly: 595-600.

Khamitov M, Wang X (Shane) and Thomson M (2019) How Well Do Consumer-Brand Relationships Drive Customer Brand Loyalty? Generalizations from a Meta-Analysis of Brand Relationship Elasticities. Journal of Consumer Research. DOI: 10.1093/jcr/ucz006.

Kock N (2015) WarpPLS 5.0 User Manual - Collaborative for International. ScriptWarp Systems, Laredo, TX. 
Lastovicka JL and Sirianni NJ (2011) Truly, Madly, Deeply: Consumers in the Throes of Material Possession Love. Journal of Consumer Research 38(2): 323-342. DOI: 10.1086/658338.

Liu C-R, Chiu T-H, Wang Y-C, et al. (2018) Generation Y's revisit intention and price premium for lifestyle hotels: brand love as the mediator. International Journal of Hospitality \& Tourism Administration 0(0): 1-23. DOI: 10.1080/15256480.2018.1464421.

Loureiro SMC and Kaufmann HR (2012) Explaining Love of Wine Brands. Journal of Promotion Management 18(3): 329-343. DOI: 10.1080/10496491.2012.696460.

Malär L, Krohmer H, Hoyer WD, et al. (2011) Emotional Brand Attachment and Brand Personality: The Relative Importance of the Actual and the Ideal Self. Journal of Marketing 75(4): 35-52. DOI: 10.1509/jmkg.75.4.35.

Malär L, Nyffenegger B, Krohmer H, et al. (2012) Implementing an intended brand personality: a dyadic perspective. Journal of the Academy of Marketing Science 40(5): 728-744. DOI: 10.1007/s11747-011-0251-8.

Marin L, Ruiz S and Rubio A (2009) The Role of Identity Salience in the Effects of Corporate Social Responsibility on Consumer Behavior. Journal of Business Ethics 84(1): 65-78. DOI: 10.1007/s10551-008-9673-8.

Netemeyer RG, Krishnan B, Pullig C, et al. (2004) Developing and validating measures of facets of customer-based brand equity. Journal of Business Research 57(2). Measurement Validation in Marketing Research: 209-224. DOI: 10.1016/S0148-2963(01)00303-4.

Nunkoo R (2018) Handbook of Research Methods for Tourism and Hospitality Management. Edward Elgar Publishing.

Oliver RL (1980) A Cognitive Model of the Antecedents and Consequences of Satisfaction Decisions. Journal of Marketing Research 17(4): 460-469.

Oliver RL (1999) Whence Consumer Loyalty? The Journal of Marketing 63: 33-44. DOI: $10.2307 / 1252099$.

Park CW, MacInnis DJ, Priester J, et al. (2010) Brand Attachment and Brand Attitude Strength: Conceptual and Empirical Differentiation of Two Critical Brand Equity Drivers. Journal of Marketing 74(6): 1-17. DOI: 10.1509/jmkg.74.6.1.

Podsakoff PM, MacKenzie SB, Lee J-Y, et al. (2003) Common method biases in behavioral research: a critical review of the literature and recommended remedies. The Journal of Applied Psychology 88(5): 879-903. DOI: 10.1037/0021-9010.88.5.879.

Preacher K and Hayes A (2004) SPSS and SAS procedures for estimating indirect effects in simple mediation models. Behavior research methods, instruments, \& computers : a journal of the Psychonomic Society, Inc 36(4): 717-731.

Preacher KJ and Hayes AF (2008) Asymptotic and resampling strategies for assessing and comparing indirect effects in multiple mediator models. Behavior Research Methods 40(3): 879-891. 
PTA (2018) Telecom Indicators. Available at:

http://pta.gov.pk/index.php?option=com_content $\&$ task=view $\&$ id=269\&Itemid=658 $($ accessed 18 October 2017).

Rauschnabel PA and Ahuvia A (2014) You're so lovable: Anthropomorphism and brand love. Journal of Brand Management 21(5): 372-395. DOI: 10.1057/bm.2014.14.

Rauschnabel PA, Krey N, Babin BJ, et al. (2016) Brand management in higher education: The University Brand Personality Scale. Journal of Business Research 69(8): 3077-3086. DOI:

10.1016/j.jbusres.2016.01.023.

Rodrigues P, Reis R and Cantista I (2015) Consumer Behavior: How the "Brand Love" Affects you. In: Ideas in Marketing: Finding the New and Polishing the Old. Developments in Marketing Science: Proceedings of the Academy of Marketing Science. Springer, Cham, pp. 583-588. DOI: 10.1007/978-3-319-10951-0_212.

Rosch E (1978) Principles of Categorization. In: Cognition and Categorization. Hillsdale, NJ: Lawrence Erlbaum, pp. 27-48.

Roy P, Khandeparkar K and Motiani M (2016) A lovable personality: The effect of brand personality on brand love. Journal of Brand Management 23(5): 97-113. DOI: 10,1057/s41262-016-0005-5.

Roy SK, Eshghi A and Sarkar A (2013) Antecedents and consequences of brand love. Journal of Brand Management 20(4): 325-332. DOI: 10.1057/bm.2012.24.

Sethuraman R (2001) What Makes Consumers Pay More for National Brands than for Store Brands Image or Quality? ID 310883, SSRN Scholarly Paper, 15 March. Rochester, NY: Social Science Research Network. Available at: https://papers.ssrn.com/abstract=310883 (accessed 10 August 2017).

Sheth JN (1971) Word-of-Mouth Low-Risk Innovations. Journal of Advertising Research 11: 15-18.

Shimp TA and Madden TJ (1988) Consumer-Object Relations: a Conceptual Framework Based Analogously on Sternberg's Triangular Theory of Love. ACR North American Advances NA-15: 163-168ahlu.

Tabachnick BG and Fidell LS (2013) Using Multivariate Statistics, 6th Edition. Boston: Pearson International Edition.

Thomson M, MacInnis DJ and Whan Park C (2005) The Ties That Bind: Measuring the Strength of Consumers' Emotional Attachments to Brands. Journal of Consumer Psychology 15(1): 77-91. DOI: $10.1207 / \mathrm{s} 15327663 j \mathrm{jp} 1501 \_10$.

Tuominen P (1999) Managing Brand Equity. Liiketaloudellinen aikakauskirja: The Finish Journal of Business 48(1): 65-100.

Turgut MU and Gultekin B (2015) The Critical Role of Brand Love in Clothing Brands. Journal of Business Economics and Finance 4(1): 126-152. 
Ülkümen G, Chakravarti A and Morwitz VG (2010) Categories Create Mind-Sets: The Effect of Exposure to Broad Versus Narrow Categorizations on Subsequent, Unrelated Decisions. Journal of Marketing Research 47(4): 659-671. DOI: 10.1509/jmkr.47.4.659.

Vemuri AW and Costanza R (2006) The role of human, social, built, and natural capital in explaining life satisfaction at the country level: Toward a National Well-Being Index (NWI). Ecological Economics 58(1): 119-133. DOI: 10.1016/j.ecolecon.2005.02.008.

Vernuccio M, Pagani M, Barbarossa C, et al. (2015) Antecedents of brand love in online network-based communities. A social identity perspective. Journal of Product \& Brand Management 24(7): 706-719. DOI: 10.1108/JPBM-12-2014-0772.

Warren C, Batra R, Loureiro SMC, et al. (2019) Brand Coolness. Journal of Marketing 83(5): 36-56. DOI: $10.1177 / 0022242919857698$.

Washburn JH and Plank RE (2002) Measuring Brand Equity: An Evaluation of a Consumer-Based Brand Equity Scale. Journal of Marketing Theory and Practice 10(1): 46-62. DOI: 10.1080/10696679.2002.11501909.

Westbrook RA (1987) Product/Consumption-Based Affective Responses and Postpurchase Processes. Journal of Marketing Research 24(3): 258-270. DOI: 10.2307/3151636.

Wetzels M, Odekerken-Schröder G and van Oppen C (2009) Using PLS Path Modeling for Assessing Hierarchical Construct Models: Guidelines and Empirical Illustration. MIS Quarterly 33(1): 177195.

Yoo B and Donthu N (2001) Developing and validating a multidimensional consumer-based brand equity scale. Journal of Business Research 52(1): 1-14. DOI: 10.1016/S0148-2963(99)00098-3.

Zeithaml VA, Berry LL and Parasuraman A (1996) The Behavioral Consequences of Service Quality. Journal of Marketing 60(2): 31-46. DOI: 10.2307/1251929.

Zhao X, Jr JGL and Chen Q (2010) Reconsidering Baron and Kenny: Myths and Truths About Mediation Analysis. Journal of Consumer Research 37: 197-206.

**** Insert Appendix I here **** 


\section{Higher-Order Utilitarian and Symbolic Antecedents of Brand Love and Consumers' Behavioral Consequences for Smartphones}

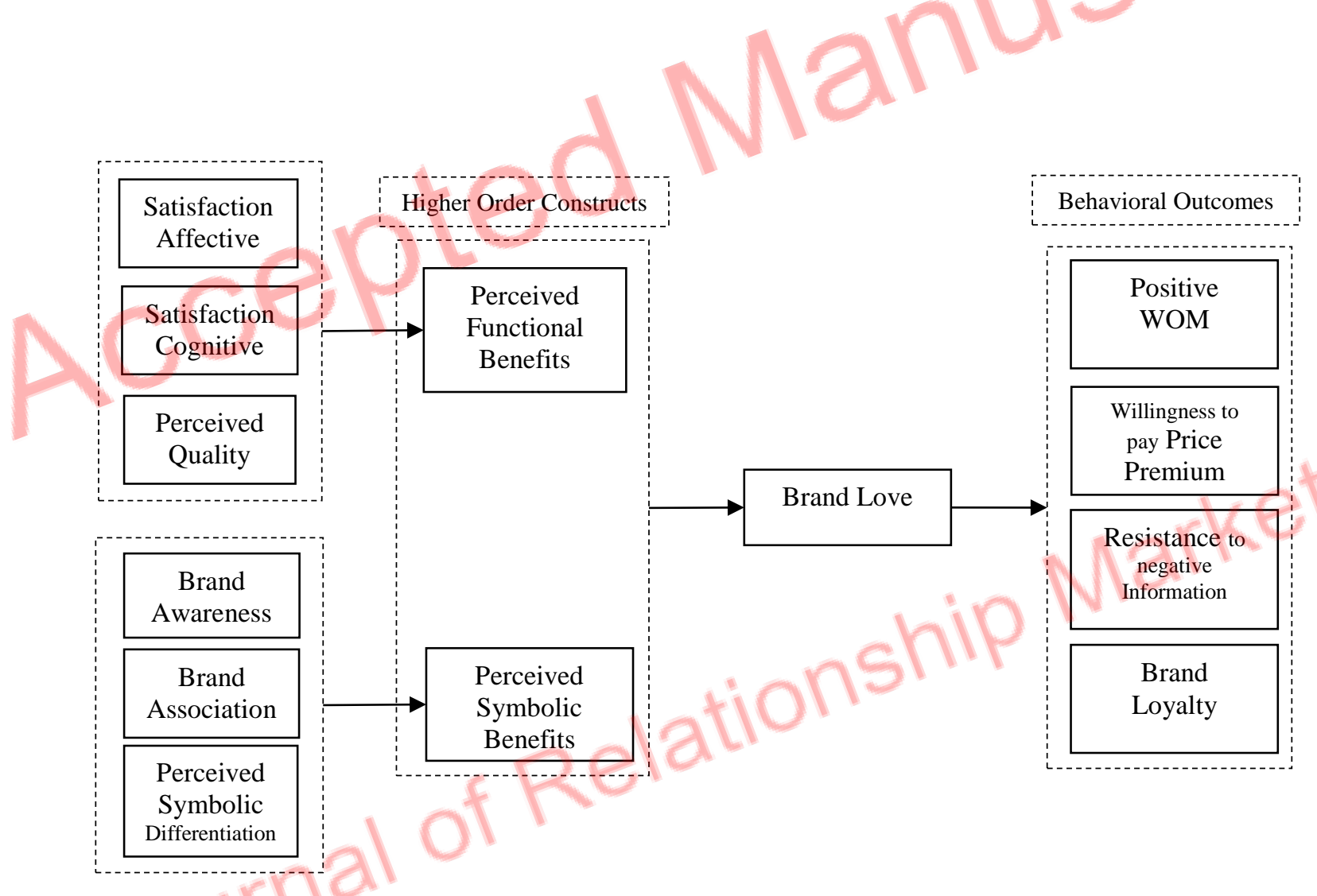

Figure 1: Conceptual Framework of the Study 


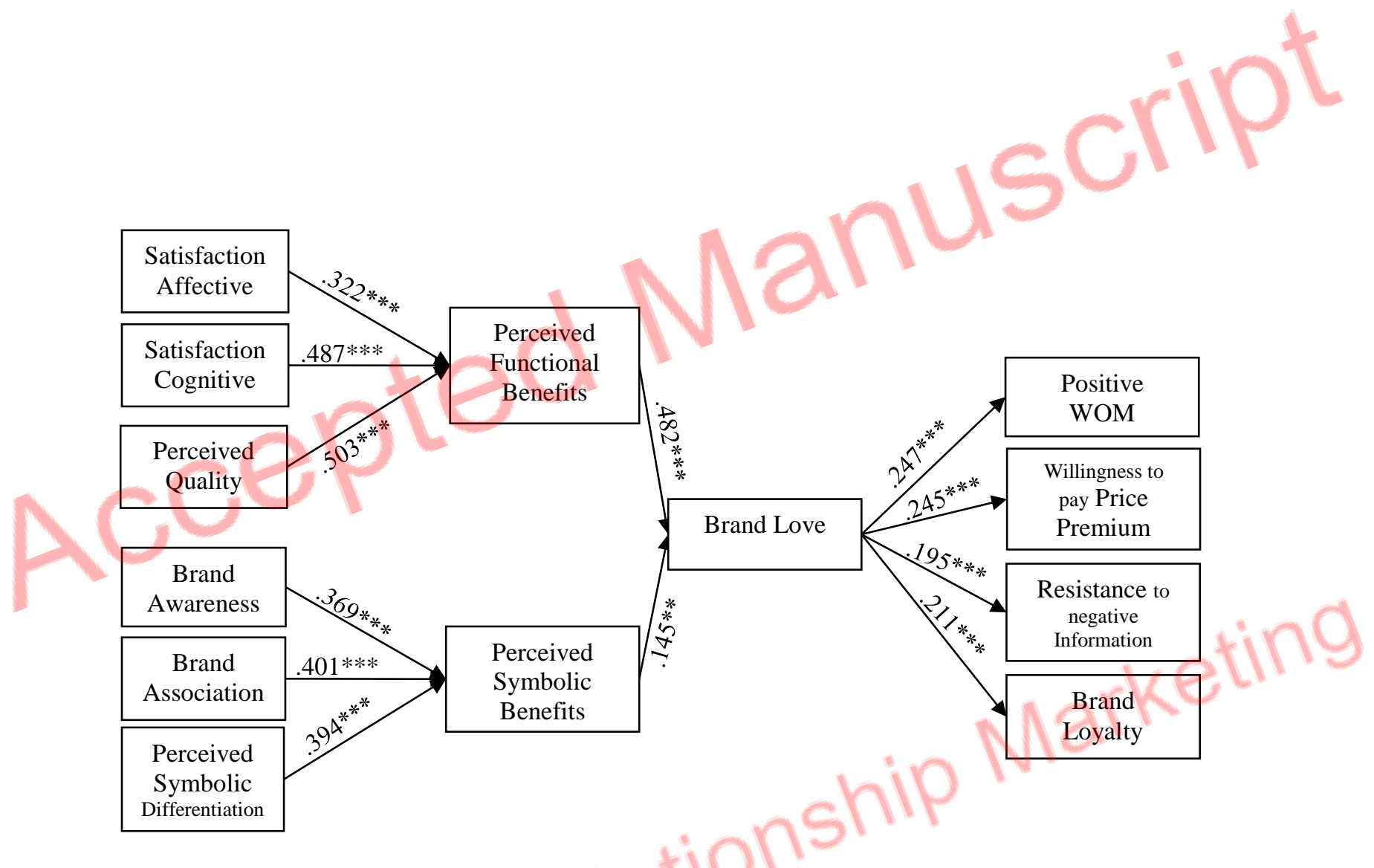

Figure 2: Results 
Table 1: Mean, Standard Deviations and Discriminant Validity among various Constructs

\begin{tabular}{|c|c|c|c|c|c|c|c|c|c|c|c|c|c|}
\hline & 1 & 2 & 3 & 4 & 5 & 6 & 7 & 8 & 9 & 10 & 11 & 12 & 13 \\
\hline 1. PWOM & 0.875 & & & & & & & & & & & & \\
\hline 2. PP & 0.579 & 0.839 & & & & & & & & & & & \\
\hline 3. RTNI & 0.418 & 0.379 & 0.868 & & & & & & & & & & \\
\hline 4. Loyalty & 0.639 & 0.689 & 0.516 & 0.803 & & & & & & & & & \\
\hline 5. Br Love & 0.213 & 0.201 & 0.206 & 0.171 & 0.835 & & & & & & & & \\
\hline 6. Aware & 0.457 & 0.488 & 0.45 & 0.519 & 0.077 & 0.897 & & & & & & & \\
\hline 7. SatAff & 0.211 & 0.232 & 0.179 & 0.214 & 0.69 & 0.117 & 0.808 & & & & & & \\
\hline 8. Quality & 0.641 & 0.463 & 0.439 & 0.555 & 0.172 & 0.473 & 0.215 & 0.823 & & & & & \\
\hline 9. BASB & 0.651 & 0.510 & 0.434 & 0.619 & 0.155 & 0.568 & 0.172 & 0.574 & 0.843 & & & & \\
\hline 10. PSD & 0.56 & 0.501 & 0.375 & 0.475 & 0.175 & 0.504 & 0.184 & 0.510 & 0.66 & 0.855 & & & \\
\hline 11. PFB & 0.642 & 0.658 & 0.489 & 0.696 & 0.388 & 0.564 & $\mathrm{n} / \mathrm{a}$ & $\mathrm{n} / \mathrm{a}$ & 0.641 & 0.521 & 0.729 & & \\
\hline 12. PSB & 0.659 & 0.589 & 0.494 & 0.635 & 0.162 & $\mathrm{n} / \mathrm{a}$ & 0.187 & 0.613 & $\mathrm{n} / \mathrm{a}$ & $\mathrm{n} / \mathrm{a}$ & 0.679 & 0.848 & \\
\hline 13. SatCog & 0.485 & 0.684 & 0.406 & 0.677 & 0.134 & 0.563 & 0.18 & 0.464 & 0.576 & 0.394 & $\mathrm{n} / \mathrm{a}$ & 0.602 & 0.862 \\
\hline Mean & 5.06 & 5.07 & 5.21 & 4.86 & $0.02^{a}$ & 4.56 & 5.19 & 5.09 & 5.03 & 5.11 & 4.90 & 5.06 & 4.90 \\
\hline Std. & 1.90 & 1.19 & 1.31 & 1.29 & $0.81^{\mathrm{a}}$ & 1.50 & 1.20 & 1.25 & 1.33 & 1.24 & 1.15 & 0.92 & 1.35 \\
\hline
\end{tabular}

Note: Correlations are under the main diagonal, and square root of AVEs are on the main diagonal.

$P W O M=$ Positive word-of-mouth, $P P=$ Price premium, $R T N I=$ Resistance to negative information, $B A S B=B r a n d$ associations to symbolic

benefits, $P S D=$ Perceived symbolic differentiation, $P F B=$ Perceived functional benefits, $P S B=$ perceived symbolic benefit,

SatCog=Satisfaction cognitive, SatAff= Satisfaction affective

a based on factor scores

$n / a=$ not applicable because of higher order factors 
Table 2: Model Fit and Quality Indices

\begin{tabular}{|c|c|c|}
\hline Model Fit and Quality Indices & Status & Fit Criteria \\
\hline Average path coefficient $(\mathrm{APC})=0.120, \mathrm{P}=0.007$ & Accepted & $\mathrm{p}<.05$ \\
\hline Average R-squared $(\mathrm{ARS})=0.102, \mathrm{P}<0.016$ & Accepted & $\mathrm{p}<.05$ \\
\hline Average adjusted R-squared (AARS) $=0.089, \mathrm{P}<0.027$ & Accepted & $\mathrm{P}<.05$ \\
\hline Average block VIF $(\mathrm{AVIF})=1.168$ & Good Fit & Acceptable if $<=5$, Ideally $<=3.3$ \\
\hline Average full collinearity VIF (AFVIF) $=1.963$ & Good Fit & Acceptable if $<=5$, Ideally $<=3.3$ \\
\hline Tenenhaus GoF $(\mathrm{GoF})=0.285$ & Medium & small $>=0.1$, medium $>=0.25$, large $>=0.36$ \\
\hline Sympson's paradox ratio $(\mathrm{SPR})=0.955$ & Good Fit & Acceptable if $>=0.7$, Ideally $=1$ \\
\hline R-squared contribution ratio $(\mathrm{RSCR})=0.996$ & Good Fit & Acceptable if $>=0.9$, Ideally $=1$ \\
\hline $\begin{array}{l}\text { Statistical suppression ratio (SSR) }=0.909 \\
\text { Nonlinear bivariate causality direction ratio }\end{array}$ & Good Fit & Acceptable if $>=0.7$ \\
\hline$(\mathrm{NLBCDR})=0.818$ & Good Fit & Acceptable if $>=0.7$ \\
\hline
\end{tabular}


Table 3: PLS-SEM Analysis Results

\begin{tabular}{|c|c|c|c|c|c|c|c|}
\hline \multirow{2}{*}{$\begin{array}{l}\text { Independent } \\
\text { Variables }\end{array}$} & \multicolumn{7}{|c|}{ Dependent Variables (Direct Paths) } \\
\hline & $\begin{array}{l}\text { Brand } \\
\text { Love }\end{array}$ & PFB & PSB & $\begin{array}{l}\text { Brand } \\
\text { Loyalty }\end{array}$ & PWOM & PP & RTNI \\
\hline Gender & & & & -.040 & .018 & -.038 & -.016 \\
\hline Age & & & & -.061 & -.082 & -.091 & .086 \\
\hline Income & & & & $-.114 *$ & $-.110^{*}$ & $-.093^{*}$ & -.035 \\
\hline Education & & & & $115 \%$ & & $.135 * *$ & .012 \\
\hline PFB & $.482 * * *$ & & & & & & \\
\hline PSB & $.145^{* *}$ & & & & & & \\
\hline Brand Love & & & & $.211 * * *$ & $.247 * * *$ & $.245 * * *$ & $.195 * * *$ \\
\hline Perceived Qua & & $03 * *$ & & & & & \\
\hline SatCog & & & & & & & \\
\hline SatAff & & $322 * *$ & & & & & \\
\hline Brand Awaren & & & $369 * * *$ & & & & \\
\hline BASB & 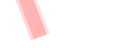 & & $401 * * *$ & & & & \\
\hline PSD & & & $394 * * *$ & & & & \\
\hline
\end{tabular}

Note. $n=321 ;$ Where $* * * p<.001, * * p<.01, * p<.05$.

$P W O M=$ Positive word-of-mouth, $P P=$ Price premium, $R T N I=$ Resistance to negative information, BASB=Brand associations to symbolic benefits, $P S D=$ Perceived symbolic differentiation, $P F B=$ Perceived functional benefits, $P S B=$ perceived symbolic benefit,

SatCog=Satisfaction cognitive, SatAff= Satisfaction affective 


\begin{tabular}{|c|c|c|}
\hline \multirow[b]{2}{*}{ Mediated Relationships } & \multicolumn{2}{|c|}{ Indirect Effects } \\
\hline & $\begin{array}{l}\text { Test Statistic } \\
\text { (p-value) }\end{array}$ & $\begin{array}{l}\text { 95\% C.I. } \\
\text { [L.L - U.L.] }\end{array}$ \\
\hline PFA $\rightarrow$ Brand Love $\rightarrow$ PWOM & $4.083(.001)$ & {$[.063-.183]$} \\
\hline PFA $\rightarrow$ Brand Love $\rightarrow$ PP & $4.056(.001)$ & {$[.063-.182]$} \\
\hline PFA $\rightarrow$ Brand Love $\rightarrow$ RTNI & $3.347(.001)$ & {$[.040-.157]$} \\
\hline PFA $\rightarrow$ Brand Love $\rightarrow$ Brand Loyalty & $3.583(.001)$ & {$[.048-.163]$} \\
\hline PSA $\rightarrow$ Brand Love $\rightarrow$ PWOM & $2.244(.024)$ & {$[.008-.071]$} \\
\hline PSA $\rightarrow$ Brand Love $\rightarrow$ PP & $2.239(.025)$ & {$[.008-.071]$} \\
\hline PSA $\rightarrow$ Brand Love $\rightarrow$ RTNI & $2.078(.037)$ & {$[.006-.059]$} \\
\hline PSA $\rightarrow$ Brand Love $\rightarrow$ Brand Loyalty & $2.138(.032)$ & {$[.006-.063]$} \\
\hline
\end{tabular}




\section{Appendix I (Measurement items and factor loadings)}

Satisfaction Affective: $\quad(\mathrm{CR}=.882, \alpha=.821)$

$\mathrm{x}_{1} \quad$ Using this smartphone puts me in good mood.

$\mathrm{x}_{2} \quad$ I am very happy with this smartphone brand.

$\mathrm{x}_{3}$ This smartphone brand is likeable.

$\mathrm{X}_{4}$ This smartphone brand is trustworthy.

Satisfaction Cognitive: $\quad(\mathrm{CR}=\mathbf{. 9 2 0}, \alpha=.884)$

$\mathrm{x}_{1} \quad$ This smartphone is a good value of money.

$\mathrm{x}_{2} \quad$ I am satisfied with the innovative features of this smartphone brand.

$\mathrm{x}_{3}$ This smartphone is a unique brand in this category.

$\mathrm{X}_{4} \quad$ I am satisfied with the functional quality of this smartphone brand.

Brand Associations to Symbolic Benefits: $\quad(C R=.907, \alpha=.863)$

$\mathrm{x}_{1} \quad$ I think this smartphone has a very unique brand image, compared to competing brands. $\quad .808$

$\mathrm{x}_{2} \quad$ I respect and admire people who use this smartphone.

$\begin{array}{lll}\mathrm{X}_{3} & \text { I like and trust the company that makes this smartphone brand products. } & .884\end{array}$

\begin{tabular}{ll}
$\mathrm{X}_{4}$ & I like the brand image of this smartphone. \\
\hline
\end{tabular}

Brand Awareness: $\quad(\mathrm{CR}=.925, \alpha=.878)$

I think attributes of this smartphone brand quickly come to my mind.

$\mathrm{x}_{2}$ I can quickly recognize this smartphone brand among other competing brand. 906

$\mathrm{X}_{3} \quad$ I am familiar with this smartphone brand.

Perceived Quality: $\quad(\mathrm{CR}=.862, \alpha=.759)$

$\mathrm{x}_{1} \quad$ I trust the quality of the products from this smartphone brand.

$\mathrm{x}_{2} \quad$ I think products from this smartphone brand would be of very good quality.

$\mathrm{X}_{3} \quad \mathrm{I}$ think products from this smartphone brand offer excellent features.

Perceived Symbolic Differentiation: $\quad(C R=.891, \alpha=.816)$

$\mathrm{x}_{1} \quad$ It makes sense to buy this smartphone instead of any other brand, even if they are the same.

$\mathrm{x}_{2}$ If another brand is not different from this smartphone in any way, it seems smarter to purchase this.

$\mathrm{x}_{3} \quad$ Even if another brand has the same features as this smartphone, I would prefer to buy this.

Brand Love: $\quad(\mathrm{CR}=.932, \alpha=.910, \mathrm{VIF}=1.262)$

$\mathrm{F}_{1} \quad$ Higher Order Factor: Self-Brand Integration

$\mathrm{F}_{2} \quad$ Higher Order Factor: Passion Driven Behaviors

$\mathrm{F}_{3} \quad$ Higher Order Factor: Positive Emotional Connection $\quad .890$

$\begin{array}{ll}\mathrm{F}_{4} \quad \text { Long-Term Relationship } & .737\end{array}$

$\begin{array}{lll}\mathrm{F}_{5} & \text { Anticipated Separation Distress } & .713\end{array}$

$\begin{array}{lll}\mathrm{F}_{6} \quad \text { Attitude Valence } & .780\end{array}$

Brand Loyalty: $\quad(\mathrm{CR}=.915, \alpha=.889, \mathrm{VIF}=\mathbf{2 . 7 9 7})$

$\begin{array}{ll}\mathrm{X}_{1} \quad \text { I would consider myself loyal to this smartphone brand. } & .727\end{array}$

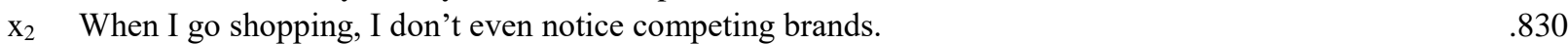

$\begin{array}{lll}\mathrm{x}_{3} & \text { This smartphone would be my first choice. } & .848\end{array}$

\begin{tabular}{ll}
$\mathrm{X}_{4}$ & I would feel this is the only smartphone brand I need. \\
\hline
\end{tabular}

$\mathrm{x}_{5} \quad$ I'll 'do without' rather than buy another brand.

$\mathrm{x}_{6} \quad$ Think if this smartphone brand were not available, it would make little difference to you if you had

Positive WOM: $\quad(\mathrm{CR}=.907, \alpha=.847, \mathrm{VIF}=\mathbf{2 . 2 2 2})$

$\mathrm{X}_{1} \quad$ I have said positive things about this smartphone brand to other people.

$\begin{array}{lll}\mathrm{x}_{2} & \text { I have encouraged other people to buy this smartphone brand. } & .890\end{array}$

\begin{tabular}{ll}
$\mathrm{X}_{3}$ & I have recommended this smartphone brand to people who seek your advice. \\
\hline
\end{tabular}

Willingness to pay Price Premium: $\quad(\mathrm{CR}=.877, \alpha=.790, \mathrm{VIF}=\mathbf{2 . 2 8 1})$

$\mathrm{X}_{1} \quad$ Buying this smartphone brand seems like a good idea, although more expensive. $\quad .845$

$\begin{array}{lll}\mathrm{X}_{2} & \text { I am willing to pay a higher price for my favorite smartphone brand. } & .861\end{array}$

$\begin{array}{lll}\mathrm{X}_{3} & \text { I will continue to buy this smartphone brand even identical brands are cheaper. } & .811\end{array}$

Resistance to Negative Information: $\quad(\mathrm{CR}=.901, \alpha=.836, \mathrm{VIF}=1.511)$

$\mathrm{x}_{1} \quad$ I readily change my views about my most liked smartphone brand based on negative information about it. (R) 
$\mathrm{x}_{2} \quad$ I think negative information about my most liked smartphone brand has no effect on me.

$\mathrm{x}_{3}$ Negative information about my most liked smartphone changes the way I think about the brand.(R)

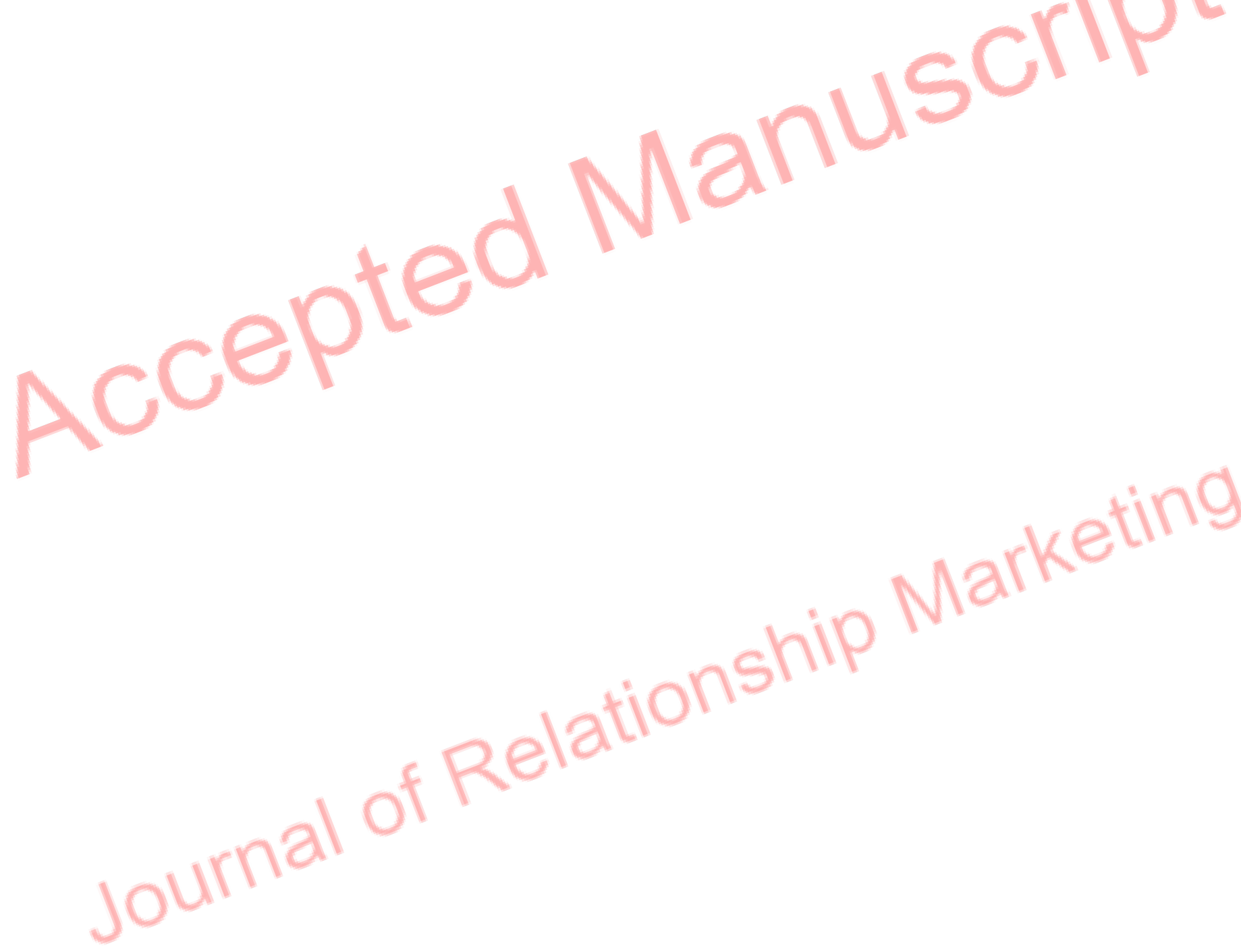

